\title{
COMBINING DIARY AND GUIDED STRATEGIES FOR WRITING DIFFICULTIES
}

\author{
1,2 Ismiati \& ${ }^{1}$ Iin Lailatul Fitria \\ ${ }^{1}$ Faculty of Teacher Training and Education, Cordova University, Indonesia \\ ${ }^{2}$ Corresponding Author Email: ismiatisumarlin08@gmail.com
}

\begin{tabular}{|c|c|}
\hline Article Info & Abstract \\
\hline $\begin{array}{l}\text { Article History } \\
\text { Received: October } 2020 \\
\text { Revised: December } 2020 \\
\text { Published: January } 2021\end{array}$ & $\begin{array}{l}\text { This study aims to identify the students' writing difficulties and combined Diary } \\
\text { and guided strategies as a solution to solve or reduce the writing difficulties. } \\
\text { Diary and guided writing are two strategies that are commonly separately } \\
\text { implemented in writing classes. Among the number of strengths, there must be }\end{array}$ \\
\hline $\begin{array}{l}\text { Keywords } \\
\text { Writing Difficulties; } \\
\text { combining Diary; } \\
\text { Guided Strategies; }\end{array}$ & $\begin{array}{l}\text { weaknesses when diary writing is implemented without any feedback. Writing } \\
\text { without continuous guidance may not optimally help students reducing the } \\
\text { writing difficulties. This study tried to combine both of those strategies. Students } \\
\text { at the English study program were randomly selected as the research } \\
\text { participants. The qualitative approach was applied. The data was obtained by } \\
\text { implementing diary writing combined with guidance during one month as well as } \\
\text { an observation, an in-depth interview, and a Focus Group Discussion. The result } \\
\text { shows that students got difficulties applying proper vocabulary, grammar, and } \\
\text { mechanics in their writing. Grammar was the most difficult aspect. Further } \\
\text { finding describes that the combination of Diary and guided strategies could } \\
\text { continuously reduce the writing difficulties. }\end{array}$ \\
\hline
\end{tabular}

How to cite: Ismiati \& Fitria, I. L. (2021). Combining Diary and Guided Strategies for Writing Difficulties, JOLLT Journal of Languages and Language Teaching, 9(1), 14-23. DOI: https://doi.org/10.33394/jollt.v\%vi\%i.3096

\section{INTRODUCTION}

Good writing covers some rules such as language use accuracy, mechanical, content, stylistic, and judgment. The complexities of English writing rules still become big challenges for many students at the university level, including those who study English as a major specialization. Ismiati and Pebriantika (2019) found that writing is one of the most difficult courses for most English Study Program students. Barra (2001), as cited in Thipatdee (2019), identified students' mistakes in spelling, punctuation, content ambiguity, and redundancy. At the same point, Sakkir (2020) explained that writing is a complex skill and sometimes difficult to teach because it requires a grammatical device and conceptual and judgment elements. As a complex skill, writing needs to continuously practice and feedback. Various strategies have been studied and implemented in the class of writing to help students who are struggling with better writing skills. Each strategy has its own values and weaknesses. It can be appropriate or may not for a certain group of learners.

Diary and guided writing are two strategies that are commonly separately implemented in the class of writing. Diary strategy is a constant individual writing practice as a part of the learner-center approach in which a writer controls his own writing. Guided strategy means giving supervision, encouragement, and control toward the students' writing practice. It is commonly applied to guide and control individual writing through which students have opportunities to discuss, do exercise, and revise their writing. Parson (2001) defines Guided Writing as the process where teachers develop and guide students' writing through discussion, join text construction, and evaluation of their independent writing. 
Many studies found that diary writing could improve students' writing skills or solve writing problems. Maharani (2017) found that the writing ability of students at the English Department of a certain University in Semarang was significantly increased by using Diary writing strategy. Langan (2008) stated that continuously writing on a diary can make students develop their thinking habit and make the writing as part of their life activity.

Among the number of strengths, there must be weaknesses when Diary writing is practiced without feedback or guidance. Some studies found that Diary writing strategy without continuous guidance neither improves the writing ability nor overcomes the writing problems. It more improves the students' feeling, writing habit, and motivation rather than the ability to create the accuracy of writing. Herliani, Linuih, Dwijananti (2015) found that diary writing without any feedback could improve students' learning motivation or behavior rather than the progress of the writing ability. Ismiati and Pebriantika (2019) found the combination of Diary and Guided strategies was one of the recommended strategies for writing class. It was claimed that the use of the Diary writing strategy without any guidance, control, or feedback makes many students focus their writing mostly on the content as an expression of their feeling and gave little attention to the linguistic features' correctness. According to Ifanc (2010), in order to make progress in writing skills, learners need teachers' guidance to help them get progress and solve problems of their writing skills.

Regarding to the weaknesses of applying Diary writing without any feedback as found by Ismiati and Pebriantika (2019) and Herliani, Linuih, and Dwijananti (2015), this study was conducted to identify the students' writing problems and combine Diary and guided strategies as a solution to overcome or reduce the writing problems. A combination of this study's strategies was implemented by first instructed the students to constantly write at home then regularly and continuously accept writing feedback from the lecturers every week.

\section{RESEARCH METHOD \\ Research Design}

This research applied a qualitative descriptive approach. Data was collected through some techniques such as in-depth interviews, implementation of Diary and guided strategies, observation, and FGD technique. To get an In-Depth clear description of the students' writing difficulties, five students as participants of this research were individually interviewed. Simultaneously, to identify the students' individual writing difficulties and know how the combination of Diary and Guided Strategies become a solution to overcome the students' writing difficulties, the students were instructed to practice Diary writing at home and given individually guided. They wrote four topics for a week and guided twice in a week during one month. In each meeting of guiding activity, each student had two topics to be discussed with the guider/lecturer. Each topic of the students' essay consisted of at least 500 hundred words. There were three lecturers who guided the students' writing. Each lecturer guided seven students for each week. The total meetings for guiding during one month were eight times. In guiding, each guide or lecturer gave feedback based on the students' individual writing difficulties. The diary and guided strategies also are as a technique to identify how the combination of Diary writing and guided writing strategies overcome or reduce students' writing problems individually, observation was done every week during the process of guiding. To get deep data on how the combination of Dairy and Guided strategies becomes a solution for the students' writing difficulties, FGD was conducted to seven students randomly taken from the research participants. This study's subjects were 20 students who were randomly selected from the first until the eighth grade at the English Study Program of Cordova University. 


\section{Instruments}

Some instruments were used to collect data. Interview and Focus Group Discussion (FGD) guidelines were prepared as the instruments used during the process of interview and FGD. Observation sheet was the instrument used to collect data through observation. Writing guide cards were the instruments used to take some notes for the students' individual writing guidance. This study's data were qualitatively analyzed through several steps: organization, data reading, coding, narrating, description, themes, and interpreting.

\section{RESEARCH FINDING AND DISCUSSION \\ Research Finding \\ Writing Difficulties}

Writing in English is one of the most difficult courses for university students, even for those who study English as their major specialization. The students have to complete many written college assignments, which must be correctly written and accepted based on the English writing standard. The complexities of the writing rules in English make students get difficulties in constructing good or accepted writing. Writing difficulties mean problems or errors made by students in their writing.

Good English writing is writing, which covers its writing standard. Hammer (2004) pointed out that good writing is a complex process compared to speech. Writers need to master all features related to good writing, including a rich vocabulary, knowledge of grammar, and mechanic of writing. In this study, the students were found got difficulties in constructing good writing. The difficulties were found in some aspects, as presented in the following table.

Table 1

Writing Difficulties

\begin{tabular}{|c|c|c|c|c|}
\hline \multirow{2}{*}{ Students } & \multicolumn{4}{|c|}{ Types/aspect of difficulties } \\
\hline & Week 1 & Week 2 & Week 3 & Week 4 \\
\hline 1 & $\begin{array}{l}\text { Vocabulary, grammar, } \\
\text { mechanic }\end{array}$ & Grammar, mechanic & $\begin{array}{l}\text { Grammar, vocabulary, } \\
\text { mechanic }\end{array}$ & Grammar \\
\hline 2 & $\begin{array}{l}\text { Vocabulary, grammar, } \\
\text { mechanic }\end{array}$ & Grammar, vocabulary, & Mechanic, grammar & Grammar, mechanic \\
\hline 3 & $\begin{array}{l}\text { Vocabulary, grammar, } \\
\text { mechanic }\end{array}$ & $\begin{array}{l}\text { Grammar, vocabulary, } \\
\text { mechanic }\end{array}$ & $\begin{array}{l}\text { Grammar, vocabulary, } \\
\text { mechanic }\end{array}$ & Mechanic \\
\hline 4 & $\begin{array}{l}\text { Vocabulary, grammar, } \\
\text { mechanic }\end{array}$ & $\begin{array}{l}\text { grammar, mechanic, } \\
\text { vocabulary }\end{array}$ & Grammar, vocabulary & Grammar, vocabulary \\
\hline 5 & $\begin{array}{l}\text { Vocabulary, grammar, } \\
\text { mechanic }\end{array}$ & Grammar, mechanic & Grammar & Grammar \\
\hline 6 & $\begin{array}{l}\text { Vocabulary, grammar, } \\
\text { mechanic }\end{array}$ & Grammar, mechanics & Vocabulary, mechanic & Vocabulary \\
\hline 7 & $\begin{array}{l}\text { Vocabulary, grammar, } \\
\text { mechanic }\end{array}$ & $\begin{array}{l}\text { Grammar, mechanic, } \\
\text { vocabulary }\end{array}$ & Grammar, mechanic & $\begin{array}{l}\text { Grammar, vocabulary, } \\
\text { mechanic }\end{array}$ \\
\hline 8 & $\begin{array}{l}\text { Vocabulary, grammar, } \\
\text { mechanic }\end{array}$ & Grammar, mechanic & Grammar & vocabulary \\
\hline 9 & $\begin{array}{l}\text { Vocabulary, grammar, } \\
\text { mechanic }\end{array}$ & Grammar & $\begin{array}{l}\text { Grammar, vocabulary, } \\
\text { mechanic }\end{array}$ & Mechanic \\
\hline 10 & $\begin{array}{l}\text { Vocabulary, grammar, } \\
\text { mechanic }\end{array}$ & $\begin{array}{l}\text { Grammar, vocabulary, } \\
\text { mechanic }\end{array}$ & Grammar, vocabulary & Mechanic, grammar \\
\hline 11 & $\begin{array}{l}\text { Vocabulary, grammar, } \\
\text { mechanic }\end{array}$ & Grammar, mechanic & Grammar, mechanic & Grammar, mechanic \\
\hline 12 & $\begin{array}{l}\text { Vocabulary, grammar, } \\
\text { mechanic }\end{array}$ & $\begin{array}{l}\text { Vocabulary, grammar, } \\
\text { mechanic }\end{array}$ & Grammar, vocabulary & Vocabulary \\
\hline 13 & $\begin{array}{l}\text { Vocabulary, grammar, } \\
\text { mechanic }\end{array}$ & $\begin{array}{l}\text { Vocabulary, grammar, } \\
\text { mechanic }\end{array}$ & Grammar, vocabulary & Grammar, vocabulary \\
\hline 14 & $\begin{array}{l}\text { Vocabulary, grammar, } \\
\text { mechanic }\end{array}$ & $\begin{array}{l}\text { Grammar, mechanic. } \\
\text { vocabulary }\end{array}$ & Grammar, vocabulary & Mechanic \\
\hline 15 & Grammar, mechanic, & Grammar, mechanic & Grammar, vocabulary & Vocabulary \\
\hline
\end{tabular}




\begin{tabular}{cllll}
\hline \multicolumn{2}{c}{ vocabulary } & & & \\
\hline 16 & $\begin{array}{l}\text { Vocabulary, grammar, } \\
\text { mechanic }\end{array}$ & $\begin{array}{l}\text { Vocabulary, grammar, } \\
\text { mechanic }\end{array}$ & Vocabulary, grammar & Grammar \\
\hline 17 & $\begin{array}{l}\text { Vocabulary, grammar, } \\
\text { mechanic }\end{array}$ & $\begin{array}{l}\text { Vocabulary, grammar, } \\
\text { mechanic }\end{array}$ & Grammar, mechanic & \\
\hline 18 & $\begin{array}{l}\text { Grammar, vocabulary, } \\
\text { mechanic }\end{array}$ & $\begin{array}{l}\text { Grammar, vocabulary, } \\
\text { mechanics }\end{array}$ & Grammar, vocabulary & Vocabulary, mechanic \\
\hline 19 & $\begin{array}{l}\text { Vocabulary, grammar, } \\
\text { mechanic }\end{array}$ & $\begin{array}{l}\text { Vocabulary, grammar, grammar, vocabulary } \\
\text { mechanic }\end{array}$ & mechanic \\
\hline 20 & $\begin{array}{l}\text { Vocabulary, grammar, } \\
\text { mechanic }\end{array}$ & $\begin{array}{l}\text { Vocabulary, grammar, } \\
\text { mechanic }\end{array}$ & Vocabulary, mechanic & mechanic \\
\hline
\end{tabular}

\section{Discussion}

This study aims to identify the students' difficulties in writing and combine Diary and guided strategies as a solution to overcome or reduce the difficulties. Many studies found that diary writing is one of effective strategies to improve the students' writing skills as described by Maharani (2017) found that the writing ability of students at the English Department of a certain University in Semarang was significantelly increased by using Diary writing strategy.

In contrast, this study believed that the use of Diary writing strategy without continuous feedback or guidance could not help students reduce writing problems. This study supported the previous research findings, which showed that diary writing could not optimally effective to improve the students' writing skills without feedback. Herliani found, Linuih, Dwijananti (2015) that diary writing without any feedback could more improve students' learning motivation or behavior rather than progress of the writing ability. At the same point, Ismiati and Pebriantika (2019) claimed that the combination of Diary and Guided strategies was recommended for writing class. Moreover, the researchers found that Diary writing strategy without any guidance, controlling, or feedback makes many students focus their writing mostly on the content as an expression of their feeling and give little attention to the linguistic features' correctness. This study continued the previous research finding conducted by Ismiati and Pebriantika (2019) that recommended the combination of Diary and guided strategies in teaching writing. This study identified how those strategies combined effectively to reduce the students' writing difficulties. In addition, it is agreed that a writing guide is useful for the students' writing progress. Ifanc (2010) stated that in order to make progress in writing skills, learners, in this case, need teachers' guidance to help them make progress and solve problems of their writing skills.

Finding of this study shows that those students got some difficulties in writing as presented in Table 1. The use of Diary writing practice combined with guided strategy, could continuously help students reduce the difficulties in writing. It describes that students got writing difficulties in the aspect of vocabulary, grammar, and mechanics. It shows that students had limited vocabulary, lack knowledge of grammar and mechanics. Among the three aspects of the writing difficulties, using grammar errors were mostly found in all topics of students' diary writing. Students' problems with using mechanics and the difficulties in selecting appropriate words were also faced when they completed almost all Diary writing task topics.

Many students got problems in choosing appropriate words for a certain context. Wrong word errors in the students' writing refer to the word choice that students made for a sentence or context which may convey a slightly different meaning from what they mean. The students got confused in use some words which are similar in meaning, sound, and spelling. Such words as quite-quiet-quiet, affect-effect, loose- lose. When the students wrote quickly, they made a mistake in using word forms, such as the use of a verb instead of an adjective that directly changed the meaning. Another case was found that students used non-standard 
vocabulary like 'gonna and wanna' in their writing. Such a word is acceptable in formal writing.

The difficulties in the grammar aspect got by the students were found in the form of tenses pattern, article, preposition, pronoun, conjunction, and coherence among sentences. Most students were lack knowledge of grammar. Grammatical accuracy was the most difficult thing to be completed in their writing. The form of tenses was not correctly used. They used wrong form of the verb to describe about activities in a certain time. For example, they often make a mistake to use the correct form of verb when they talk about their daily activities and experiences. The most common errors of the verbs were found when the students describe about someone else's daily activities. Most students were confused about using irregular verbs.

It was found that about $85 \%$ of students were not able to demonstrate articles in their sentences. They did not understand the different use of the article 'a' and 'an'. They often use wrong article to refer to a certain thing or place. The students got difficulty placing preposition. In an example, the preposition 'on, of, for, in, at' was often misused.

In using pronoun, it was found that the pronoun did not clearly refer to definite referents, many students have failed in the use of subject pronoun and possessive pronoun, and object pronoun. They were confused to use the subject pronoun 'they and it' to refer to a statement, plants, animals, a group of people, and other things. Misplaced of the possessive adjective ' her, his, our, its' were often found in the students' writing. Object pronoun 'him, them, and her' were the most misused.

Almost $90 \%$ of students got problems constructing a unified paragraph. They got little understanding on the correct use of grammatical cohesion. They did not know how to use the type of cohesive devices or conjunction adequately in their writing. The sentences were not coherently constructed. The students made the wrong choice of conjunction to connect the sentences in a paragraph as an example the use of 'furthermore, moreover, because of, since' were often used for inappropriate context. The same type of cohesive device is often frequently used in different sentences. For example, the use of the adversative conjunction' then and after that' was more frequently used.

In the case of mechanical errors, many students made a common mistake in the use of capitalization, punctuation, spelling. The students did omission and addition in the use of punctuation. 'Comma' was often omitted and added to some sentences. The students added 'comma' in sentences where it was not needed, and they did not use it in a place where it must be used, such as after word, phrase, or clause to clarify the sentences. The use of capital letters for proper noun and the first word in sentences was often ignored by many students. Unnecessary capitalization was also found in the sentences. Misspelling was the most common mistake did by students in the aspect of mechanic were found in spelling. Many students wrote misspelled words in their writing.

Most students had the same difficulties in constructing a good writing. Hammer (2004) pointed that good writing has to cover the complexities of vocabulary, knowledge of grammar, and mechanics. Finding of this study shows that $80 \%$ of the participants have limited vocabulary to be developed in their writing. Limited vocabulary makes them write less or more frequently use the same words in the writing. They did not apply variation of words. Almost $90 \%$ of the students got difficulties in the aspect of grammar. They had lack knowledge how to construct sentences correctly. $75-80 \%$ of the students did not use mechanics properly.

In writing the Diary, the students mostly focused to express their feeling and idea than paying more attention to the accuracy of the writing. They directly adopt the words from dictionary without knowing the appropriateness of the meaning of the words with what they mean to convey in their writing. Most of the students firstly wrote in Indonesian language 
than translated into English. In the process of translating the Indonesian writing, they mostly followed the structure of their source language rather which is far different from the standard of English writing as the target language of their writing. The such writing was not accepted in English writing standard.

They also often make mistake of the word spelling. They missed some letters of the word that can make their writing misinterpreted. Most students use wrong word to indicate a certain context. They directly adopted the word from dictionary or translation tool without paying attention to the appropriateness of the word in a certain use.

Combining Diary and guided strategy in this study was conducted by asking students to do the Diary writing task and accepted the writing guided from the lecturers as the guiders. The students from the first until the eight grades at English Study program were asked to write on a diary during four weeks. They wrote and developed four topics for each week then accepted writing guided twice a week during one month.

Each topic of the students' writing must consisted of at least 500 words. The students were given individual writing guided by the lecturers of English Study Program. Guided writing strategy in this research refers to the process of giving supervision toward the result of students' diary writing. Guided writing activities were completed in eight times for each student. In the process of guided, each student had opportunities to discuss, ask question, accept clear explanation, and revise their writing. The lecturers as the writing guide had chance to help students individually in constructing a good paragraph, reducing the writing difficulties as well as revising the errors in the student's writing.

The individual writing guided lasted in fifteen to twenty minutes. The process of writing guided began by asking the students to describe about the topic of the writing being discussed. The lecturers then asked them in which part of their writing which they considered difficult. The lecturers gave explanation based on the students 'difficulties and errors found in their writing. Before starting the current writing guided activity, the lecturers spent a few minutes to review the previous discussion.

To evaluate or observe the students' understanding or progress at the end of guidance, the lecturer asked the student to write new a short paragraph which has the same types, form, and structure with the topics of writing being discussed. In addition, to reduce the limitation of vocabulary and grammar, the lecturer applied exercises and explanation related to the topic, content, and types of the students' writing being discussed. At last, the students made some revisions on their writing. During the revising activity, students got more understanding on the correct form of the errors. They moreover had great opportunities to check and correct the use of grammar to make their writing become more relevant and unified.

On the first day of writing guided, each student had two topics of writing to be discussed with the lecturers as the writing guide. Each topic consisted of 300 to 400 words. In the two topics of the students' writing, there found various errors in the aspect of vocabulary, grammar, and mechanics. Almost all students got the same difficulties in constructing good sentences and unified paragraph. The students mostly focused to express their feeling in writing the Diary rather than giving more attention to the accuracy of their writing. They wrote whatever came from their mind and adopted the words from dictionary without thinking the appropriateness of the words meaning with the intended meaning they wanted to convey.

During the process of first guiding, it showed a very little progress on the use of vocabulary, reduce a little difficulties of using correct grammar and mechanics. $20 \%$ of the participants got good progress of using vocabulary, they were able to use various and appropriate vocabulary. $80 \%$ of them still got difficulties to use proper words in sentences as they still had limited vocabulary to be developed into their writing. There were only $10 \%$ of 
students got good understanding on the use of correct grammar and mechanics based on the types of their writing and 90\% did not have good knowledge of grammar and mechanics.

On the second meeting of guidance, most students still thought that they were poor at writing which is mostly occurred because of lack writing practice and no regular guiding or feedback of their writing. The students continuously discussed two topics of their writing with the lecturer. Before discussing about the next two topics, the lecturer asked the students to show and give explanation about their previous topics of writing to see the students' writing progress and understanding toward their previous writing difficulties. Almost all students claimed that the three aspects of the errors in the previous writing were still confusing. The use of proper grammar was most difficult for students. A few of them had good progress on the aspect of mechanics and vocabulary.

Regarding to the topics of writing discussed on the second meeting, the students writing consisted of 500 words. $70 \%$ of students still got problems to choose appropriate words for some sentences in their writing. They still got problems to use correct form of grammar and mechanics. Most students or $90 \%$ were unable to write coherent and unified paragraphs. They mostly made errors to connect the sentences in a paragraph and often made mistake in using punctuation among words or sentences in the paragraph. The students made more mistakes on spelling and capitalization. It shows a very little progress on the students' writing. During the process of revising and evaluating, many students could not reduce their difficulties in the aspects of grammar without guiding or explanation from the lecturers. A few of them were able to revise the errors of vocabulary and mechanics without any guidance.

Some students began to show their writing progress, reduce the writing difficulties on the third guided. Through the weekly and continuously writing guided, $40 \%$ students had improved their vocabulary. They had several words in the paragraph. They did not use the same words more frequently for different sentences. However, they were still confused to choose the appropriate words for some context in their writing. Some students or $25 \%$ of them got good understanding on the aspect of grammar and mechanics after given exercises and explanation related to the topic of writing being discussed as well as understanding on the writing discussed in the previous guiding.

The writing difficulties in the aspect of vocabulary and mechanics were much more reduced through the continuously writing guided in the fourth and the fifth meeting. $60 \%$ of the students were able to use proper mechanics in the topics being discussed in the forth meeting of the writing guided. Some words were variously and appropriately used in sentences. $40 \%$ of the students still had limited vocabulary and got problem to select proper words and mechanics for certain sentences. Only $35 \%$ of students could reduce their problems in grammar during the process of revision and evaluation and $70 \%$ still got a difficulty.

Grammar was the most difficult aspect for most students at the English study program. The knowledge of grammar got progress on the fifth writing guided. The process of writing guided, exercises, and explanations from the lecturers showed that $50 \%$ of students used correct grammar forms. They could differ the use of regular and irregular verbs and the use of tenses in writing about their experiences. $75 \%$ of the students were able to reduce the problems of using punctuation. They did not use punctuation in a wrong place or add it to the sentence inwhich it was not needed. $70 \%$ of them got good progress in applying vocabulary in the writing. They were good in choosing and developing the words for each sentence in a paragraph of their writing.

During the writing guided on the sixth meeting, almost $80 \%$ of students did the exercises and revisions on the aspects mechanics and vocabulary without any help from the lecturers. They could reduce their writing errors in the use of punctuation, capitalization, and spelling. Most of the students had new words for their writing, and they were able to put the word appropriately in sentences. $60 \%$ of the students had good knowledge of using grammar 
to write about their daily live activities and experiences. They used correct forms of verbs or tenses in many parts of their writing. They correctly constructed sentences to create relevant, coherent, and unified paragraphs.

The students' writing difficulties was continuously reduced as long as they took serious writing guided and paid more attention during the process of guiding. Most students got continuous and much more progress until the last meeting of guiding. On the seventh until the last guided, $90 \%$ of the students made only a little mistake on the aspects of mechanics and vocabulary. Many students or $75 \%$ got good progress in using correct grammar. Most students at the last meeting were able to complete the writing exercises and reduce their writing difficulties related to the sixteen topics which had been discussed during the period of writing guided process.

Combination of Diary and guided strategy in this study was offered as solution for the students' writing difficulties. It was believed as one of better way to help students got progress of their writing ability and reduced writing errors. Through regular and continuously guided, students learnt more for individual difficulties in writing as they accepted writing guide based on their own writing difficulties. Students had opportunities to have and discuss individual exercises, realize and revise their writing errors.

After finishing the writing guided activities, the participants were interviewed and gathered in a discussion to have a brief view about their writing difficulties and the impact of implementing the diary writing combined with writing guided strategy to reduce their difficulties. It was found that most students enjoyed and motivated to practice diary writing and got good progress of their writing ability because of the regular and constant writing activities. Most students were able to reduce their writing difficulties through continuously writing guided activities.

Trustcoot (2004) claimed that direct feedback or direct corrective feedback may give negative influence toward the students' overall writing. It may influence the students' fluency in writing. In contrast, this study found that direct guiding for the students' writing make students become more active and motivated to write and feel more confidence to improve their writing ability and reduce their difficulties.

\section{CONCLUSION}

This study aims to identify the students' writing difficulties and combined Diary and guided strategies as a solution to solve or reduce the writing difficulties. In writing, students still face difficulties in creating good paragraphs or a full genre. It happens because they have a lack of vocabulary, grammar, and practice. To reduce these writing challenges, teachers provided students with diaries and clues to write. This study was focused on those difficulties through giving various writing practices. Based on the data, the conclusion of this study showed that students got writing difficulties in vocabulary, grammar, and mechanics, and grammar was the most dominant. Combining Diary and guide writing strategy was proven to be one of the effective ways to solve or to reduce the students' difficulties.

\section{ACKNOWLEDGEMENT}

The researchers would like to express our gratitude to the Ministry of Research, Technology, and Higher Education as the research funder in 2020. 


\section{REFERENCES}

Abdulkareem, N. M. (2013). An invastigation study of academic writing problems faced by arab post graduate students at University of Teknology Malaysia (UTM). Journal Theory and Practice in Language Studies, 3(9). DOI: https://doi.org/10.4304/tpls.3.9.1552-1557

Alfaki, M. I. 2015. University Students' English Writing Problems: Diagnosis and Remedy. International Journal for English Language Teaching, 3(3). pp. 40-52.

Hanan, A. Taqil, Rahima, S. Akbar, N., Abdulmohsen, A., \& Dashtil. (2015). The Effect Of Diary Writing on EFL Students' Writing and Language Ability. British Journal of Education. 3(2). Pp. 75-91

Hattie, J. \& Timperley, H. 2007. The Power of Feedback. Review of Educational Research. 7(1) Pp. 81-112. DOI: https://doi.org/10.3102/003465430298487

Hammer, J. (2004). How to Tech Writing. Essex. England: Longman Group Ltd. Retrieved from www.longman.com.

Ismiati \& Pebriantika, E. (2019). Designing Strategies for University Students' Writing Skills. JOLLT Journal of Language and Language Teaching, 8(1). Pp 8-19. DOI: https://doi.org//10.33394/jolt.v8i1.2210

Ifanc, C. 2010. Guidance on the Teaching of Writing Skills: INSET Opportunities for Teachers of All Subjects Across the Curriculum at Key Stage 2 and 3 (Welsh Assembly Government, 2010). Retrieved from www.cimru.gov.uk.

Lyons, B. P. Elmedni, B. Brooklyn, LIU. 2015. Writing Skills Development for graduate Students: Workshop Intervention Using a Students-Centred Learning Approach. Journal of Education and Social Policy. Vol. 2. No. 1. March 2015. Center for Promting Idea, USA. Retrieved from www.jespnet.com.

Lan. Yu-Feng. Hung, Ling, C. HSU. Ju, H. et al. (2011). Effects of Guided Writing Strategies on Students' Writing Attitude Based on Media Richness Theory. The Turkish Online Journal of Educational Technology. October 2011. Vol. 10. Retrieved from eric.ed.gov.

Langan. J. (2011). College Essay Writing Skills With Reading Seventh Edition: Newyork

Muharni, M. M. (2017). Improving Students' Writing through Diary Writing. Central Java: University Islam Sultan Agung Semarang. The $1^{\text {st }}$ Education and Language International Conference Proceedings Center for International Language Development of Unissula. Retrieved from download.garuda.ristekdikti.go.id.

Milaningrum, E. D., \& Gafur, A. L. (2018). The Impact of Guided Writing Technique to Develop Students' ESP Writing Skills in Balikpapan State Polytechnic. Journal of English Education and Applied Linguistics, 7(1). DOI: https://doi.org/1024127/pj.v7i1

Pratiwi, D, K., Syahrial, S., \& Arasuli, A. (2012). Students Difficulties in Writing English (A Study at the Third Semesters of English Education Program at University of Bengkulu Academic Year 2011-2012). Retrieved from http//repository.unib.ac.id/id/eprint/4406.

Parsons, S. (2001). Bookwise 4 teacher's guide. Cheltenham: Neslo Thornes Ltd. McGrawInc. Retrieved from www.mhhe.com.

Ouazeta, A. (2010). Using Diary as a Practice Tool to Improve Writing Skills. the Case of Second Year LMD Students in the Department of English. Mentouri University. Constantine, Faculty of Letters and Languages, Department of Foreign Language.

Sakkir, G. (2020). The Effectiveness of Pictures in Enhance Writing Skill of Senior High School Students. Journal of Language, Literature, and Linguistics, 1(1). https://doi.org/10.26858/interference.v1i1.12803

Sakkir, G. R,. \& Salija, Q. K. (2016). Students' Perception on Social Media in Writing Class at STKIP Muhammadiyah Rappang, Indonesia. International Journal of English Linguistics, 6(3). Doi: https://doi.org/10.5539/ijel.v6n3p170 
Tuan, T.L. (2010). Enhancing EFL Learners' Writing Skill via Journal Writing. Journal of English Language Teaching. 3(3) DOI: https://doi.org/10.5539/elt.v3n3p81

Thipatdee, G. (2019). The Development of English Writing Skills Through Technique of Sentence Skeleton and Signpost Word Analysis of English Major Students. Journal of English Language Teaching. 12(4). Doi: https://doi.org/10.5539/elt.v12n4p32

Veritasari, A. L. (2008). Using Diary to Develop Writing Ability of the Fourth Grade of Kanisius Notoyudan Yogyakarta Elementary School. Yogyakarta: Santa Dharma University. Retrievedrespository.usd.ac.id.031214 